\title{
The «red snow» of the Polar Urals (Western Siberia)
}

\author{
Yuriy Naumenko* \\ Central Siberian Botanical Garden, SB RAS, 630090, Zolotodolinskaja Str., 101, Novosibirsk, Russia
}

\begin{abstract}
Pink-red colored snow fields were sampled in the area of Ochety Lake (the Polar Urals, West Siberia) at the altitude of $272 \mathrm{~m}$ above the sea level in August 2019. Zygospores of Chlamydomonas nivalis prevailed in plant communities. Altogether, 9 species of algae have been discovered in snow samples: 7 species of Cyanoprokaryota, 1 species of Bacillariophyta and 1 species of Chlorophyta.
\end{abstract}

Tinted snow is observed rather frequently in the mountains and polar regions. Red snow was first scientifically mentioned by Horace de Saussure, a Swiss natural scientist, in 1760. He discovered it at the foot of the Alpes in the Duchy of Savoy in France [1]. Analogous findings were later noted in different areas of the Alpes, Pyrenees, in the north of Scandinavia, in Alyaska, in polar countries and other places. I. V. Palibin was the first who mention pink and red snow in the European part of Russia. In 1901, he took part in the polar expedition on "Yermak" icebreaker, where he studied flora of Franz Josef Land, Spitzbergen and Severny (Northern) island of Novaya Zemlya. He observed the red snow phenomenon on Novaya Zemlya near Mashigin Bay and in the area of Matochkin Strait where pink snow is encountered in ravines, mountain slopes, almost everywhere.

Research demonstrated that the red tint of snow is caused by the development of Chlamydomonas nivalis (F.A.Bauer) Wille algae. Communities of this algae was encountered in high mountain snow fields in polar regions all over the world. Snow algae are cold-resistant organisms that manage to grow on snow and ice. It is known from literature that algae caused "snow blooming". Dependently on the prevalence of certain types of snow algae and other organisms the tint can be different. Powerfully vegetating algae tints snow fields and ice into different colours: orange, yellow, yellowish-green, green, blue, brown [2].

Snow algae live in an environment which is called cryobiotop. Cryobionts are certain group of algae which vegetate in snow and ice in appropriate conditions. The ecology of snow algae is highly important for understanding snow and ice ecosystems. However, there is not enough environmental information about snow algae.

In 1928, T.K. Tripolitova [3] described the presence of Chlamydomonas nivalis (F.A.Bauer) Wille in West Siberia. She noted that the specie is frequently found in the nival zone of Altay mountain ridges, but did not provide any references to the

\footnotetext{
* Corresponding author: Naumenko55@ngs.ru
} 
researchers. Later N.N. Voronikhin provided data about the presence of this specie in the mountains of Polar Urals [4], based on plant collecting of 1925-1927.

\section{Materials and methods}

Snow samples werecollected in the first decade of August 2018 around Ochety Lake. The lake is located in Priuralsky district of Yamalo-Nenets Autonomous Okrug. This water body is located in a narrow intermontane valley. Multiple residuals of snow cover (Fig. AB) were found on the mountain slopes and in the ravines during the research period. Water surface area is $1.8 \mathrm{~km}^{2}$, it is a flow-through lake, a lot of creeks fall into it. The areas of the tinted snows varied from 0.5 to $20 \mathrm{~m}^{2}$, the samples were collected from the surface with the depth of not more than 5-7 cm. Geographical coordinates of sampling plot were $68^{\circ} 04^{\prime} 02^{\prime \prime} \mathrm{N}, 65^{\circ} 50^{\prime} 26^{\prime \prime} \mathrm{E} ; 272 \mathrm{~m}$. above the sea level. The material was analized under Amplival optical microscope with magnification 16 x 40. Samples were collected by I.A. Gorbunova (Central Siberian Botanical Garden). The author expresses deep appreciation for her contribution.
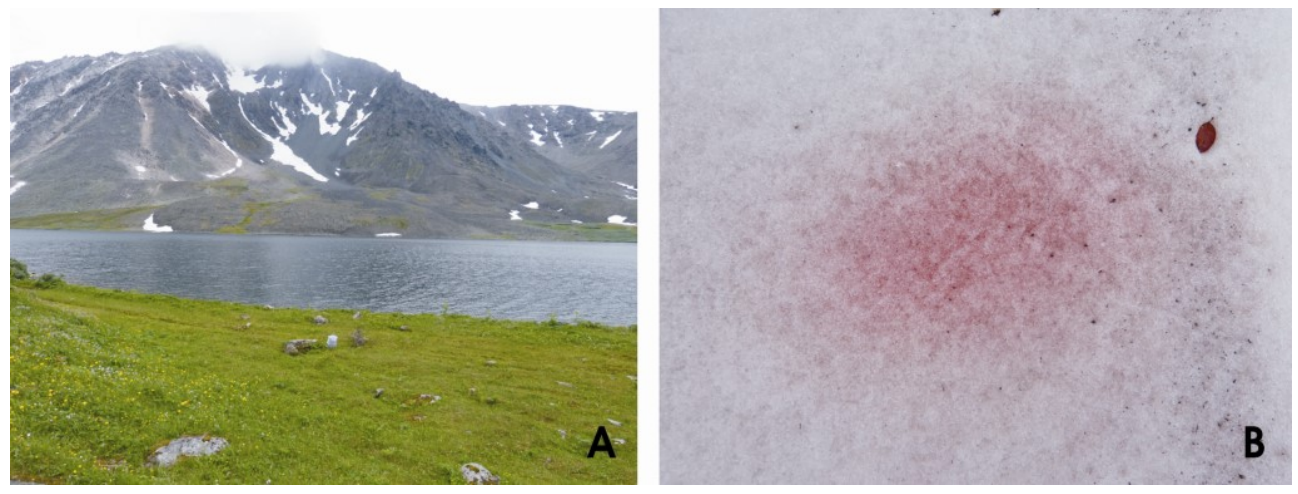

Fig. A - Ochety Lake; B - tinted snow

\section{Results and discussion}

Red-snow algae prevailed in the snow samples and it caused the tinting of snow into pink and red. The specie Chlamydomonas nivalis (F.A.Bauer) Wille (Syn. Uredo nivalis F.A. Bauer, Sphaerella nivalis (F.A. Bauer) Sommerfelt, Palmella nivalis (F.A.Bauer) W.J.Hooker Protococcus nivalis (F.A.Bauer) Agardh, Coccochloris nivalis (F.A.Bauer) Sprengel, Coccophysium nivale (F.A.Bauer) Link, Haematococcus nivalis (F.A.Bauer) Morren) is part of the family Chlamydomonadaceae of Chlorophyta taxonomic section [5]. Cells are ellipsoidal or widely ooid, from posterior and anterior view (less frequently only from a posterior view) they are widely round. The membrane is thick, layered, is uniformly thickened along the whole cell. The red pigment astaxanthin usually masks chlorophyll.

While studying the samples we discovered spherical cells with thick cellular wall surrounded by semi-transparent mucus (aplanospores) sometimes covered with mineral particles. Analogous phenomenon was observed by D. Remias et al. [6]. The cell content is red. Cilia have not been discovered in the studied material. This was a dominat specie in cryosecton of the Polar Urals. Besides, round cells (zygospores) of this specie with stellate external membranes and small round-shaped cells have been discovered. The latter were encountered much more frequently. The sizes of the cells with stellate external membranes (see the Table.) varied from 20.0 to 30.0 mym (the average diameter is 21.9 mym). The diameter of small round cells without ornamentation changed from 12.5 to 17.5 mym (the 
average dimeter is 15.4 mym). N. N. Voronikhin stated in his research (1930) that he discovered cells with uniform diameter 9.0-10.8 mym in the sample collected at the head of the river Kozhima.

Table. The linear sizes of Chlamydomonas nivalis cells collected in August 2018

\begin{tabular}{|l|c|c|c|c|c|c}
\hline $\begin{array}{l}\text { Characteristic } \\
\text { feature of a cell }\end{array}$ & $\mathbf{n}$, unit & $\begin{array}{c}\text { Actual limits, } \\
\mathbf{m y m}\end{array}$ & $\mathbf{M o}, \mathbf{m y m}$ & $\begin{array}{c}\bar{x} \pm \mathbf{S} \bar{x}, \\
\mathbf{m y m}\end{array}$ & $\mathbf{S} \mathbf{m y m}$ & $\mathbf{v , ~ \%}$ \\
\hline $\begin{array}{l}\text { Cells with } \\
\text { ornamentation }\end{array}$ & 31 & $20.0-30.0$ & 20 & $21.86 \pm 0.57$ & 3.16 & 14 \\
\hline Small cells & 35 & $12.5-17.5$ & 15 & $15.36 \pm 0.29$ & 1.73 & 11 \\
\hline
\end{tabular}

Note. $\mathrm{N}$ - number of variants in a given sample; $\bar{x}$ - average value of a characteristic; Mo - modal value of a characteristic; $\mathrm{S}$ - standart deviation of sampled population; $\mathbf{S} \bar{x}$ - statistical error; $v$ coefficient of variation.

Besides the dominat specie, 7 species of Cyanoprokaryotes were discovered in snow samples: Aphanocapsa muscicola (Menegh.) Wille (=Microcystis muscicola (Menegh.) Elenk.), Gloeocapsa alpina Näg., Chroococcus minutus (Kütz.) Näg. (=Gloeocapsa minuta (Kütz.) Hollerb.), C. turgidus (Kütz.) Näg. (=Gloeocapsa turgida (Kütz.) Hollerb.), Gloeocapsopsis magma (Brŭb.) Kom. et Anagn. (=Gloeocapsa magma (Breb.) Kütz.), Leptolyngbya foveolarum (Rabenh. ex Gom.) Anagn. et Kom. (=Phormidium foveolarum Gom.), L. frigida (Fritsch) Anagn. et Kom. (=Phormidium frigidum Fritsch, Pseudanabaena frigida (Fritsch) Anagn.). The Bacillariophytes were represented by one specie: Hantzschia amphyoxis (Ehr.) Grun. All abovementioned species were encountered singly. It is worth noting that the discovered species, according to the literature, are widely represented both in hydrophyte and soil communities. At the same time, a few species relate to a greater degree to cryobionts in terms of their ecology. Thus J. Kvíderová [7] noted Leptolyngbya foveolarum while she was studying the snow fields of Central Spitsbergen. In 1930, G. S. Filippova [8] found Chroococcus minutus and Hantzschia amphyoxis in the snow fields of the Caucasus, the latter has also been discovered in the snow fields in the mountains of Bulgaria [9]. The study of criobiontic organisms is highly important not only for botany but also for biotechnologists. These organisms contain valuable compounds such as astaxanthin and its esters, and unsaturated fatty acids. Astaxanthin protects from ultraviolet rays and is the scavenger of free radicals [6].

\section{Conclusion}

Thus, the color of the snow in the Polar Urals is caused by intense growth of Chlamydomonas nivalis. In the studied snow samples from Ochety Lake 9 species of algae have been discovered, including 7 species of the Cyanoprokaryotes, 1 species of the Bacillariophytes and 1 species of the Chlorophytes.

\section{References}

1. A.G. Salimovskaya-Rodina, Archives of biological Sciences, 43, 2-3 (1936).

2. B. Kawecka, Polish Polar Research, 7, 4 (1986).

3. T.K. Tripolitova, Izv. Tomsk state University, 79, 4 (1928).

4. N.N. Voronikhin, Proceedings of the Leningrad region of natural scientists, $\mathbf{6 0}, 3$ (1930). 
5. M.D. Guiry, G.M. Guiry, AlgaeBase, World-wide electronic publication, National University of Ireland, Galway. (2019) http://www.algaebase.org; searched on 31 July 2019.

6. D. Remias, U. Lütz-Meindl, C. Lütz, Eur. J. Phycol, 40 (2005).

7. J. Kvíderová, Czech Polar Reports, 2 (1) (2012).

8. G.S. Filippova, Izv. USSR Academy of Sciences, 7, 7 (1934)

9. J. Lukavský, V. Cepák, Nova Hedwigia, 99, 3-4 (2014). 